\title{
The Effect of Motivation on Job Satisfaction
} with Commitment as Mediation Variable (Case
Study on Online Driver Partner of Technology
Companies in Ogan Ilir Regency)

\author{
Denny Nabawi, Badia Perizade, Isni Andriana
}

\begin{abstract}
This study aims to determine the effect of motivation on job satisfaction through commitment as a mediating variable on online driver partners of technology companies in Ogan Ilir Regency. The total population of the study was 412 people. The sampling method was simple random sampling with a total sample of 202 respondents. The data analysis technique used in this research is simple linear regression, multiple regression and Sobel test to answer the hypotheses in this study. The results showed that motivation had a positive and significant effect on job satisfaction of online drivers in Ogan Ilir Regency. Motivation has a positive and significant effect on online driver commitment in Ogan Ilir Regency. Commitment has a positive and significant effect on job satisfaction of online drivers in Ogan Ilir Regency. Motivation has a positive and significant effect on job satisfaction with commitment as a mediating variable on online drivers in Ogan Ilir Regency. Some alternative suggestions that can be implemented are the provision of incentives (bonuses, vouchers, coupons), gathering events with management and online driver partners as well as being more proactive in providing feedback regarding issues that become problems for online driver partners, both from the application system or problems that occured in the work place. Further researchers are advised to use other mediating variables to link the dependent and independent variables in order to enrich the substance of the research that has been carried out such as job involvement, job stress, compensation, leadership and performance.
\end{abstract}

Keywords: Motivation, Commitment, Job satisfaction

\section{INTRODUCTION}

The development of technology in the transportation industry is growing very rapidly. Every year there is an increase in the number of vehicles which consists of motorcycles, passenger cars, buses and trucks in Ogan Ilir Regency.
Manuscript received on November 15, 2021.

Revised Manuscript received on November 19, 2021.

Manuscript published on December 30, 2021.

* Correspondence Author

Denny Nabawi*, S.E. Student, Master of Management , Economic Faculty of Sriwijaya University, Palembang, South Sumatra, Indonesia.

Prof. Badia Perizade, Lecturer, Master of Management, Economic Faculty of Sriwijaya University, Palembang, South Sumatra, Indonesia

Isni Andriana, S.E., Lecturer, Master of Management, Economic Faculty of Sriwijaya University, Palembang, South Sumatra, Indonesia

(C) The Authors. Published by Blue Eyes Intelligence Engineering and Sciences Publication (BEIESP). This is an open access article under the CC BY-NC-ND license (http://creativecommons.org/licenses/by-nc-nd/4.0/)
Table I: Number of Motorized Vehicles in Ogan Ilir Regency in 2017 s.d. 2022

\begin{tabular}{|l|c|c|c|c|}
\hline Types & 2017 & 2018 & 2019 & 2020 \\
\hline Motorcycle & 27.776 & 30.204 & $\begin{array}{c}29.85 \\
4\end{array}$ & 29.231 \\
\hline Passenger car & 4.217 & 5.204 & 5.737 & 6.305 \\
\hline Buses & 44 & 53 & 44 & 47 \\
\hline Truck & 864 & 991 & 1.016 & 1.048 \\
\hline Total & 32.901 & 36.452 & 36.652 & 38.198 \\
\hline
\end{tabular}

Data Sources: Badan Pusat Statistik, 2020

This situation is one of the reasons for the high number of online drivers in Ogan Ilir Regency through the opportunities that online driver technology companies to take the opportunity to find driver-partners. Data obtained from the Badan Pusat Statistik (BPS) of Ogan Ilir Regency in 2020, informs that the population of Ogan Ilir Regency in 2020 is 416,549 people with a growth rate of $0.87 \%$ per year. This population is spread over 16 sub-districts with the distance between the sub-districts from the Regency Capital (Indralaya) quite far. Data taken from the Badan Pusat Statistik (BPS) of Ogan Ilir Regency in 2017, explains that the furthest distance from Indralaya is 68 kilometers to Muara Kuang District and the closest is 14 kilometers to Pemulutan Barat District. Data submitted in Ekonomi.bisnis.com (2019) stated that there are 2 million to 2.5 million online drivers for the Gojek application. This number does not include online drivers for the Grab application. Meanwhile, online driver service users in 2020 for Gojek services are 3.15 million and Grab is 2.51 million (lokadata.id, 2020). Data obtained from the amount of application which downloaded in the Playstore including drivers and users in 2021 for Gojek reached 3 million people and Grab 6 million people. The number of online drivers in Palembang City has reached 48.1 thousand people (private fb group of online drivers) where Palembang City is the main based online transportation in South Sumatra. In Ogan Ilir Regency, there are two technology companies engaged in online riders. According to company data in 2021, the total number of online driver-partners in Ogan Ilir Regency is 412 people.

Published By:

Blue Eyes Intelligence Engineering \& Sciences Publication

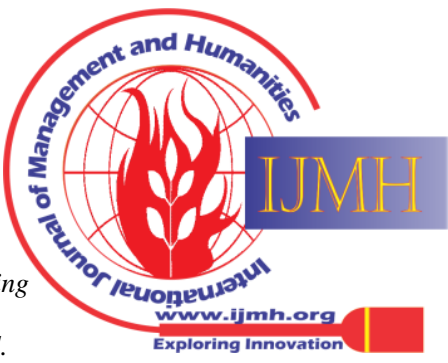




\section{The Effect of Motivation on Job Satisfaction with Commitment as Mediation Variable (Case Study on Online Driver Partner of Technology Companies in Ogan Ilir Regency)}

\section{II.LITERATURE REVIEW}

\section{A.Attribution Theory (Grand Theory)}

The main theory in this research is the attribution theory by Fritz Heider (1958) which is used to explain the relationship between motivation to job satisfaction and commitment as a mediating variable.

Attribution theory explains how a person's behavior can be formed. This theory explains how a person determines the motives and causes of a person's behavior.

\section{B. Definition of Motivation}

Armstrong (2014) explains that motivation is the strength, direction of behavior and factors that influence people to behave in certain ways. People are motivated when they expect that an action is likely to lead to the achievement of a valuable goal and reward that satisfies their needs and wants.

\section{C.Definition of Commitment}

Mowaday and Steer (1979) stated that commitment represents something more than passive loyalty to an organization but involves an active relationship with the organization so that individuals are willing to give something of themselves to contribute to the welfare of the organization. Therefore, commitment can be deduced not only from the expression of an individual's beliefs and opinions but also from his actions.

\section{D.Definition of Commitment}

Mowaday and Steer (1979) stated that commitment represents something more than passive loyalty to an organization but involves an active relationship with the organization so that individuals are willing to give something of themselves to contribute to the welfare of the organization. Therefore, commitment can be deduced not only from the expression of an individual's beliefs and opinions but also from his actions.

\section{E. Definition of Job satisfaction}

Locke (1976) defines job satisfaction as a pleasant or positive emotional state resulting from the appraisal of one's job and work experience. Feelings of pleasure when carrying out work indicate that a job is carried out without significant burdens and becomes a satisfaction for workers.

\section{F. Conceptual Framework}

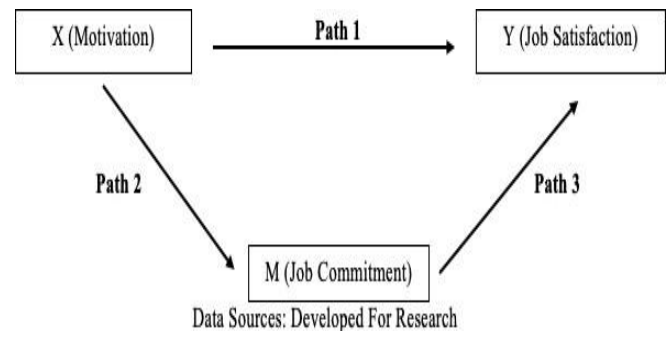

Motivation is the strength or desire that comes from every online driver to be able to fulfill their motives or desires from the work they do. This condition will affect the commitment of the driver himself. Commitment will be a mediating variable between job stress and online driver performance.

Satisfaction as an independent variable is closely related to commitment and will affect the motivation of online drivers. The more their satisfaction with the company, the higher the online driver's commitment. Commitment is also closely related to the motivation of online drivers.

\section{G. Research hypothesis}

H1: Motivation has a positive and significant effect on job satisfaction drivers from Ogan Ilir Regency

H2: Motivation has a positive and significant effect on the commitment of drivers from Ogan Ilir Regency

H3: Commitment has a positive and significant effect on jobsatisfaction online drivers in Ogan Ilir Kabupaten

H4: Motivation has a positive and significant effect on job satisfaction with commitment as a mediating variable on online drivers in Ogan Ilir Regency

\section{RESEARCH METHODS}

\section{A. Research Sites}

This research is conducted in Ogan Ilir Regency, South Sumatra, Indonesia as the research location.

\section{B. Population and Sample}

The population is a generalization of the scope consisting of objects with certain qualities and characteristics determined by researchers to be studied (Sugiyono, 2016). The population in this study were all online drivers in Ogan Ilir Regency.

The total population who work as online drivers in Ogan Ilir Regency is 412 people. (Data of Companies, 2021). Sampling using a simple random sampling technique. A good sample has an accurate and precise sample (Jogiyanto, 2008). This technique was chosen so that every member (online driver) has the same probability of being selected. The simple random sampling method is intended to be an unbiased representation of the entire population.

Determination of the sample using the slovin formula, from 412 populations in this study, the minimum number of samples used was 202.

\section{Types and Sources of Data}

The types of data processed in this study is using quantitative research. The source of data in this study is primary data. Primary data is data obtained directly from research sources (Marzuki, 2000).

\section{Data collection methods Data}

In this study, primary data was obtained directly from online driver-partners through questionnaires distributed via a google form.

\section{E. Data Analysis Techniques}

The data analysis technique in this study was carried out with a statistical test tool, SPSS version 25. Previously, the data obtained was converted with the Successive Interval Method (MSI) to change the data to have a normal distribution or meet the normal distribution requirements when using the regression test.

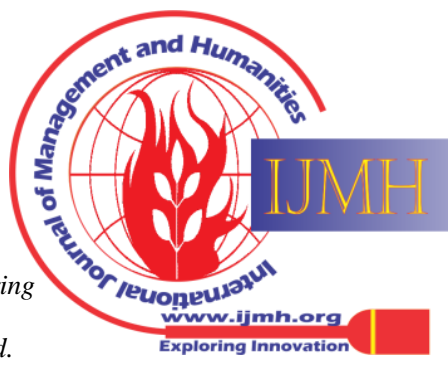




\section{RESULT AND DISCUSSION}

\section{A. The Technology Companies Providing Online DriverServices In Ogan Ilir Regency}

The technology company in Ogan Ilir Regency that is engaged in online transportation services was first present in 2017 named Ojek Kampus, addressed at Jalan Nusantara, Timbangan, Indralaya Utara, Ogan Ilir Regency.

At that time,this transportation company took advantage of the Line Business application platform, receiving a very positive response from the community, especially among Sriwijaya University students.

The founder of Ojek Kampus is an active student of Sriwijaya University named Jimmy Rifanji. This idea derived when he saw the vast area of Sriwijaya University in Indralaya and the long distance to student residential areas often became an obstacle. In addition, in the midst of intense competition in finding work, Ojek Kampus can provide a new alternative for job seekers. Until now, the total number of driver-partners is 143 people.

Then, in 2019 a new transportation service provider company emerged named Ojek Indralaya, addressed at Jalan Sarjana, Timbangan, Indralaya Utara, Ogan Ilir Regency. Muslimin as the founder is a local person of the Ogan Ilir Regency, successfully launching the Ojek Indralaya application on the Playstore in 2019. Until now, the total number of driver-partners is 269 people.

\section{B. Research Instruments Test Result}

\section{Validity Test}

Validity test were conducted to determine whether the indicators used to reflect each of its constructs. The following is a table of validity test results:

Table II : Results of Validity Test, Variable of Motivation

\begin{tabular}{ccccc}
\hline No & Indicator & r count & r table & Description \\
\hline 1 & $\mathrm{X} 1$ & 0,430 & 0,138 & Valid \\
2 & $\mathrm{X} 2$ & 0,432 & 0,138 & Valid \\
3 & $\mathrm{X} 3$ & 0,477 & 0,138 & Valid \\
4 & $\mathrm{X} 4$ & 0,524 & 0,138 & Valid \\
5 & $\mathrm{X} 5$ & 0,382 & 0,138 & Valid \\
6 & $\mathrm{X} 6$ & 0,679 & 0,138 & Valid \\
7 & $\mathrm{X} 7$ & 0,444 & 0,138 & Valid \\
8 & $\mathrm{X} 8$ & 0,405 & 0,138 & Valid \\
9 & $\mathrm{X} 9$ & 0,589 & 0,138 & Valid \\
10 & $\mathrm{X} 10$ & 0,389 & 0,138 & Valid
\end{tabular}

Table III: Results of Validity Test, Variabale of Commitment

\begin{tabular}{ccccc}
\hline No & Indicator & r count & r table & Description \\
\hline 1 & M1 & 0,546 & 0,138 & Valid \\
2 & M2 & 0,593 & 0,138 & Valid \\
3 & M3 & 0,599 & 0,138 & Valid \\
4 & M4 & 0,502 & 0,138 & Valid \\
5 & M5 & 0,725 & 0,138 & Valid \\
6 & M6 & 0,556 & 0,138 & Valid \\
\hline
\end{tabular}

Table IV: Results of Validity Test, Variable of Job satisfaction

\begin{tabular}{ccccc}
\hline No & Indicator & r count & r table & Description \\
\hline 1 & Y & 0,376 & 0,138 & Valid \\
2 & Y2 & 0,469 & 0,138 & Valid \\
3 & Y3 & 0,328 & 0,138 & Valid \\
4 & Y4 & 0,441 & 0,138 & Valid \\
5 & Y5 & 0,438 & 0,138 & Valid \\
6 & Y6 & 0,449 & 0,138 & Valid \\
7 & Y7 & 0,390 & 0,138 & Valid \\
8 & Y8 & 0,512 & 0,138 & Valid \\
9 & Y9 & 0,600 & 0,138 & Valid \\
10 & Y10 & 0,416 & 0,138 & Valid \\
11 & Y11 & 0,438 & 0,138 & Valid \\
12 & Y12 & 0,539 & 0,138 & Valid \\
13 & Y13 & 0,452 & 0,138 & Valid \\
14 & Y14 & 0,371 & 0,138 & Valid \\
Data Sources: Processed From The Ouestionnaire. 2021 &
\end{tabular}

A validity test is used to test the accuracy of a questionnaire. A questionnaire is said to be valid if the questions given can reveal and explain something to be measured through the questionnaire (Ghozali, 2018).

The test results in table II, III and IV proved that the indicator which spread to the questionnaire are valid where all the value of $r$ count is $>r$ table 0.138 with a significance of $=$ $5 \%$ and $\mathrm{n}=202$ for each question.

\section{Reliability Test}

Reliability tests were carried out to test the question of whether it could be consistent or stable over time (Ghozali, 2018). The following table of reliability test results:

Tabel V: Result of Reliability Test

\begin{tabular}{ccccc}
\hline No & Variable & r Alpha & Standard of Reliability & Description \\
\hline 1 & Motivation $\left(\mathrm{X}_{1}\right)$ & 0,621 & 0,60 & Reliable \\
2 & Commitment $(\mathrm{M})$ & 0,621 & 0,60 & Reliable \\
3 & Satisfaction $(\mathrm{Y})$ & 0,688 & 0,60 & Reliable \\
\hline \multicolumn{7}{l}{ Data Sources: Processed From The Ouestionnaire. 2021 }
\end{tabular}

Based on the results of table $\mathrm{V}$, we can conclude that all variables have $\mathrm{r}$ Alpha $>0,60$ as a standard of reliability which means the variables are reliable to be applied.

\section{Classic Assumption Test}

\section{Multicollinearity Test}

Multicollinearity test to test the regression model whether there is a correlation between variables. The basis for making multicollinearity test decisions can be seen from the tolerance value where if it is greater than $>0.10$, it means that there is no multicollinearity. Then, the VIF value, if it is smaller than $<10.00$ it means that there is no multicollinearity. The following are the results of the multicollinearity test:

Table VI : Result Of Multicollinearity Test

\begin{tabular}{llccc}
\hline \multicolumn{4}{c}{ Coefficients $^{\boldsymbol{a}}$} \\
\hline Model & Sig. & \multicolumn{2}{c}{ Collinearity Statistics } \\
& & Tolerance & VIF \\
$1 \quad$ (Constant) & 0.000 & & \\
& Motivasi & 0.386 & 0.543 & 1.840 \\
& Komitmen & 0.183 & 0.543 & 1.840 \\
\hline
\end{tabular}

Data Sources: Processed From The Ouestionnaire. 2021

Based on Table VI shows that the tolerance value is greater than $>0.10$ and the VIF value is less than $<10.00$ so that this regression model can be said that there is no multicollinearity.

\section{Heteroscedasticity Test}

A heteroscedasticity test was conducted to test the regression model whether there was an inequality of variance from the residual of one observation to another observation. The basis for the decision is that the regression model does not occur heteroscedasticity where the significance value must be more than $>0.05$ so that in this study there is no heteroscedasticity. The following are the results of the heteroscedasticity test:

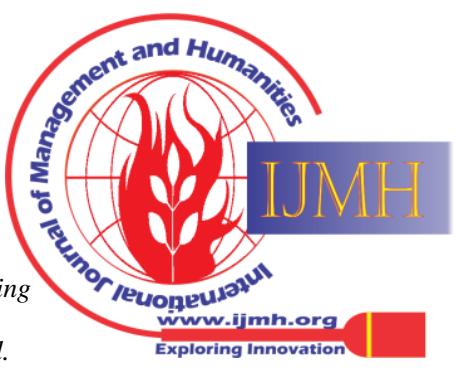


The Effect of Motivation on Job Satisfaction with Commitment as Mediation Variable (Case Study on Online Driver Partner of Technology Companies in Ogan Ilir Regency)

Table VII: Result Of Heteroscedasticity Test

\begin{tabular}{llccc}
\hline \multicolumn{5}{c}{ Coefficients $^{a}$} \\
\hline Model & Sig. & \multicolumn{2}{c}{ Collinearity } & Statistics \\
& & & $\begin{array}{c}\text { Tolera } \\
\text { nce }\end{array}$ & VIF \\
1 & (Constant) & 0.000 & & \\
& Motivasi & 0.313 & 0.543 & 1.840 \\
& Komitmen & 0.324 & 0.543 & 1.840 \\
\hline
\end{tabular}

Data Sources: Processed From The Ouestionnaire. 2021

Based on Table VII, the results of the heteroscedasticity test show that the significance value of each motivation and commitment variable to the residual value is greater than > 0.05 so that in this study there was no heteroscedasticity.

\section{Normality test}

Normality test is used to test whether the regression model is normally distributed. The conversion of ordinal to interval data has been carried out through the Successive Interval Method (MSI) to change the data so that it has a normal distribution where the significance value must be more than $>$ 0.05 . The following are the results of the normality test:

Table VIII: Result of Normality Test

\begin{tabular}{|l|l|r|r|r|}
\hline \multicolumn{5}{|c|}{ One-Sample Kolmogorov-Smirnov Test } \\
\hline \multirow{2}{|c|}{} & \multicolumn{1}{|c|}{ Motivation } & Commitment & Satisfaction \\
\hline $\mathrm{N}$ & 202 & 202 & 202 \\
\hline \multirow{2}{*}{$\begin{array}{l}\text { Normal } \\
\text { Parameters }{ }^{\mathrm{a}, \mathrm{b}}\end{array}$} & Mean & 35.11 & 20.31 & 48.20 \\
\cline { 2 - 5 } $\begin{array}{l}\text { Most Extreme } \\
\text { Differences }\end{array}$ & Atd. Deviation & 1.301 & 1.279 & 2.529 \\
\cline { 2 - 5 } & Posolute & 0.151 & 0.108 & 0.176 \\
\cline { 2 - 5 } & Negative & 0.068 & 0.062 & 0.097 \\
\hline Test Statistic & -0.151 & -0.108 & -0.176 \\
\hline Asymp. Sig. (2-tailed) & 0.151 & 0.108 & 0.176 \\
\hline \\
Data Sources: Processed From The Questionaire, 2021 \\
\hline
\end{tabular}

Based on Table VIII, the results of the normality test show that each research variable are normally distributed where the motivation variable has a significance value of 0.064 , the commitment variable is 0.092 , and the satisfaction variable is 0.087 greater than $>0.05$.

\section{Path Analysis Through Regression Techniques}

\section{* Significance Test of the Direct Effect of Motivation on Satisfaction}

To measure the direct effect of motivation on job satisfaction, the $t$ statistic test was carried out. The criteria have a significant effect if the t-count value is smaller than the $\mathrm{t}$-table value of 0.05 . The following are the results of the t-statistical test of the direct effect of motivation (X) on satisfaction (Y):

Table IX: Statistical Test $\mathbf{t}$ Motivation Variables on Satisfaction

\begin{tabular}{|c|c|c|c|c|c|c|}
\hline \multicolumn{7}{|c|}{ Coefficients $^{a}$} \\
\hline \multirow{2}{*}{\multicolumn{2}{|c|}{ Model }} & \multicolumn{2}{|c|}{$\begin{array}{c}\text { Unstandardized } \\
\text { Coefficients }\end{array}$} & \multirow{2}{*}{$\begin{array}{c}\text { Standardized } \\
\text { Coefficients }\end{array}$} & \multirow[t]{2}{*}{$t$} & \multirow[t]{2}{*}{ Sig. } \\
\hline & & $B$ & Std. Error & & & \\
\hline \multirow[t]{2}{*}{1} & (Constant) & 40.646 & 3.170 & & 12.822 & 0.000 \\
\hline & Motivation & 0.515 & 0.090 & 0.167 & 2.400 & 0.000 \\
\hline
\end{tabular}

a. Dependent Variable: Job Satisfaction

Data Sources: Processed From The Questionnaire, September 2021

Based on Table IX, it is known that the constant (a) value is 40.646 while the Motivation value (b / regression coefficient) is 0.515 so that the regression equation can be written:

$\mathrm{Y}=\mathrm{a}+\mathrm{bX}$

$\mathrm{Y}=40.646+0.515 \mathrm{X}$
The equation can be explained that the constant of 40.646 means that the consistent value of the satisfaction variable is 40.646. While the regression coefficient $X$ of 0.515 states that for every $1 \%$ addition to the motivation value, the satisfaction value increases by 0.515 . The regression coefficient is positive so that it can be said that the direction of the influence of the variable $\mathrm{X}$ on $\mathrm{Y}$ is positive and significant with a significance value of t-count less than 0.000 than $<0.05$.

Based on the values and explanations above, it shows that Hypothesis 1 (H1) is accepted that motivation has a positive and significant effect on job satisfaction of online drivers in Ogan Ilir Regency.

\section{* Significance Test of the Effect of Motivation on Commitment}

To measure the effect of motivation on commitment, it is done by performing the t statistic test. The criteria have a significant effect if the t-count value is smaller than the t-table value of 0.05 . The following are the results of the $t$ statistical test for the direct effect of motivation (X) on commitment(M):

Table X: Statistical Test $\mathbf{t}$ Motivation Variables on Commitment

\begin{tabular}{|c|c|c|c|c|c|c|}
\hline \multicolumn{7}{|c|}{ Coefficients $^{a}$} \\
\hline \multirow{2}{*}{\multicolumn{2}{|c|}{ Model }} & \multicolumn{2}{|c|}{$\begin{array}{c}\text { Unstandardized } \\
\text { Coefficients }\end{array}$} & \multirow{3}{*}{$\begin{array}{c}\begin{array}{c}\text { Standardized } \\
\text { Coefficients }\end{array} \\
\text { Beta } \\
\end{array}$} & \multirow[t]{2}{*}{$t$} & \multirow[t]{2}{*}{ Sig. } \\
\hline & & $B$ & Std. Error & & & \\
\hline \multirow[t]{2}{*}{1} & (Constant) & 2.219 & 1.406 & & 1.579 & 0.016 \\
\hline & Motivation & 0.515 & 0.040 & 0.676 & 12.964 & 0.000 \\
\hline
\end{tabular}

Based on Table X, it is known that the constant (a) value is 2.219 while the Motivation value (b / regression coefficient) is 0.515 so that the regression equation can be written:

$$
\begin{aligned}
& \mathrm{M}=\mathrm{a}+\mathrm{bX} \\
& \mathrm{M}=2.219+0.515 \mathrm{X}
\end{aligned}
$$

The equation can be explained that the constant of 2.219 means that the consistent value of the commitment variable is 2.219. While the regression coefficient $X$ of 0.515 states that for every $1 \%$ addition to the motivation value, the commitment value increases by 0.515 . The regression coefficient is positive so that it can be said that the direction of the influence of the variable $\mathrm{X}$ on $\mathrm{M}$ is positive and significant with a significance value of $\mathrm{t}$-count less than 0.000 than $<0.05$. Based on the values and explanations above, it shows that Hypothesis 2 (H2) is accepted that motivation has a positive and significant effect on the commitment of online drivers in Ogan Ilir Regency.

\section{* Significance Test of the Effect of Commitment} on JobSatisfaction

To measure the effect of commitment on job satisfaction, the $\mathrm{t}$ statistic test was carried out. The criteria have a significant effect if the t-count value is smaller than the t-table value of 0.05 . The following are the results of the $t$ statistical test the direct effect of commitment (M) on satisfaction (Y):

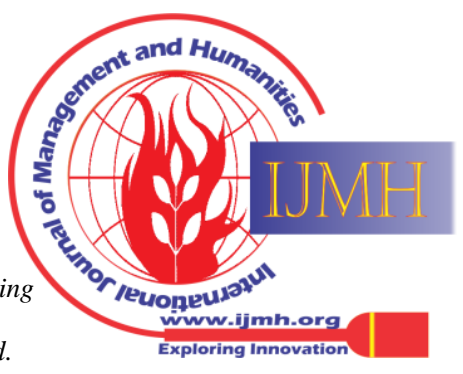


Table XI: Statistical Test t Variable Commitment to Job Satisfaction

\begin{tabular}{|c|c|c|c|c|c|c|}
\hline \multicolumn{7}{|c|}{ Coefficients $^{a}$} \\
\hline \multirow{2}{*}{\multicolumn{2}{|c|}{ Model }} & \multicolumn{2}{|c|}{$\begin{array}{c}\text { Unstandardized } \\
\text { Coefficients }\end{array}$} & \multirow{2}{*}{$\begin{array}{c}\text { Standardized } \\
\text { Coefficients }\end{array}$} & \multirow[t]{2}{*}{$t$} & \multirow[t]{2}{*}{ Sig. } \\
\hline & & $B$ & Std. Error & & & \\
\hline \multirow[t]{2}{*}{1} & (Constant) & 41.980 & 2.412 & & 17.407 & 0.000 \\
\hline & Commitment & 0.306 & 0.117 & 0.182 & 2.612 & 0.010 \\
\hline
\end{tabular}

Based on Table XI, it is known that the constant (a) value is 41.980 while the Commitment value (b / regression coefficient) is 0.306 so that the regression equation can be written:

$\mathrm{Y}=\mathrm{a}+\mathrm{bM}$

$\mathrm{Y}=41.980+0.306 \mathrm{M}$

The equation can be explained that the constant of 41,980 means that the consistent value of the satisfaction variable is 41,980. While the regression coefficient $\mathrm{M}$ of 0.306 states that for every $1 \%$ addition to the value of commitment, the value of job satisfaction increases by 0.306 . The regression coefficient is positive so that it can be said that the direction of the influence of the variable $\mathrm{M}$ on $\mathrm{Y}$ is positive and significant with a significance value of $t$ arithmetic less than 0.000 than $<0.05$.

Based on the values and explanations above, it shows that Hypothesis 3 (H3) is accepted that commitment has a positive and significant effect on job satisfaction of onlinedrivers in Ogan Ilir Regency.

* Significance Test of the Effect of Motivation on Job Satisfaction with Commitment as Mediator

To measure the effect of motivation on job satisfaction with commitment as a mediator, it is done by performing multiple regression statistical tests. The results of the regression test were then compared with the coefficients of the direct influence of motivation on job satisfaction to determine whether the commitment variable as a mediator acts as a perfect mediating variable, partially (partial) or not as a mediating variable. The following are the results of the multiple regression statistical test of the influence of motivation on job satisfaction with commitment as a mediator:

Table XII: Statistical Test $\mathbf{t}$ Motivation Variables on Commitment

\begin{tabular}{|c|c|c|c|c|c|c|}
\hline \multicolumn{7}{|c|}{ Coefficients $^{a}$} \\
\hline \multirow{2}{*}{\multicolumn{2}{|c|}{ Model }} & \multicolumn{2}{|c|}{$\begin{array}{c}\text { Unstandardized } \\
\text { Coefficients }\end{array}$} & \multirow{2}{*}{$\begin{array}{c}\text { Standardized } \\
\text { Coefficients } \\
\text { Beta }\end{array}$} & \multirow[t]{2}{*}{$t$} & \multirow[t]{2}{*}{ Sig. } \\
\hline & & $B$ & Std. Error & & & \\
\hline \multirow[t]{3}{*}{1} & (Constant) & 40.174 & 3.183 & & 12.620 & 0.000 \\
\hline & Motivation & 0.106 & 0.121 & 0.082 & 0.870 & 0.000 \\
\hline & Commitment & 0.213 & 0.059 & 0.126 & 1.336 & 0.000 \\
\hline
\end{tabular}

Data Sources: Processed From The Questionnaire, September 2021

Based on Table XII, it is known that the constant (a) value is 40,174 while the Motivation value (b / regression coefficient) is 0.106 and the Commitment value (b/ regression coefficient) is 0.213 , then the regression equation can be written:

$\mathrm{Y}=\mathrm{a}+\mathrm{cIX}+\mathrm{bM}$

$\mathrm{Y}=40.174+0.106 \mathrm{X}+0.213 \mathrm{M}$

The equation can be explained that the constant of 40,174 means that the consistent value of the satisfaction variable is 40,174 . While the regression coefficient of motivation (CI) is 0.106 and the regression coefficient of commitment is 0.213 .

Then for every $1 \%$ addition of each variable of motivation and commitment, the value of job satisfaction increases by the regression coefficient of the variable.

Based on the criteria for fulfilling the characteristics of the mediating variable, the values (a) and (b) are significant at a significance level of 0.000 , where the cI value is also significant at 0.000 . While the value of the coefficient of $\mathrm{cI}$ is 0.106 less than $<$ the value of the coefficient $b 0.213$. Then the value of the coefficient $b$ decreased from the effect of commitment on satisfaction of 0.306 (see table XI) to 0.213 through multiple regression test with motivation on job satisfaction.

Based on the fulfillment of these criteria, the mediating variable of commitment is said to be a partial mediation variable. Then to determine the level of significance of hether the relationship through the mediating variable is icantly able to act as a mediator in the relationship. To find out, it is done through of a significance test with the Sobel Test, the following is the solution equation:

$$
\begin{aligned}
& Z=\frac{\mathrm{a} \cdot \mathrm{b}}{\sqrt{\left(b^{2} \cdot S E a^{2}\right)+\left(\left(a^{2} \cdot S E b^{2}\right)\right.}} \\
& Z=\frac{0,515 \cdot 0,213}{\sqrt{\left(0,213^{2} \cdot 0,090^{2}\right)+\left(0,515^{2} \cdot 0,059^{2}\right)}} \\
& Z=\frac{0,109695}{\sqrt{0,000367+0,000923}} \\
& Z=\frac{0,109695}{0,03591657}
\end{aligned}
$$

\section{$Z=3,054$}

From the results of the Sobel test calculation above, the $\mathrm{Z}$ value of 3.054 is obtained. Because the $Z$ value of 3.054 is greater than 1.97 ( $\mathrm{t}$ table value, $\mathrm{n}=202$ ), it can be concluded that the mediation coefficient is significant and has a mediating effect.

Based on the value and significance test in the explanation above, it shows that Hypothesis 4 (H4) is accepted that motivation has a positive and significant effect on Job Satisfaction with Commitment as a mediating variable on online drivers in Ogan Ilir Regency.

\section{* Analysis of Correlation Coefficient (r) and Coefficient of Determination (R2)}

The analysis of correlation coefficient (r) is intended to determine the relationship of independent variable to the endent variable. The coefficient of determination $\left(\mathrm{R}^{2}\right)$ is test the goodness-fit of the regression model (Ghozali, 2018). The correlation coefficient test (r) and the coefficient of determination $\left(\mathrm{R}^{2}\right)$ can be seen in the results of the regression table in the summary model (Ghozali, 2018). Here are the results of the regression test of the relationship between variables: The Relationship between Motivation on Job Satisfaction:

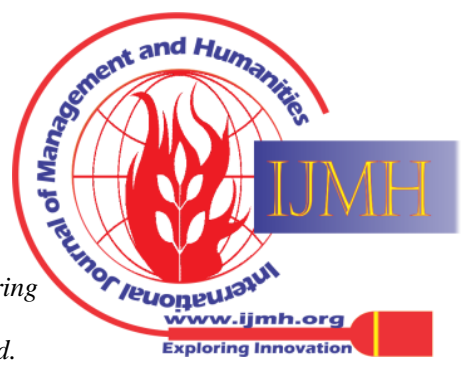




\section{The Effect of Motivation on Job Satisfaction with Commitment as Mediation Variable (Case Study on Online Driver Partner of Technology Companies in Ogan Ilir Regency)}

Table XIII: The Analysis of Correlation Coefficient (r) and Coefficient of Determination (R2) Motivation on Job Satisfaction

\begin{tabular}{|l|c|c|c|r|}
\hline \multicolumn{5}{|c|}{ Model Summary } \\
\hline Model & $R$ & $R$ Square & $\begin{array}{c}\text { Adjusted } R \\
\text { Square }\end{array}$ & $\begin{array}{c}\text { Std. Error of } \\
\text { the Estimate }\end{array}$ \\
\hline 1 & $0.467^{\mathrm{a}}$ & 0.218 & 0.203 & 3.464 \\
\hline
\end{tabular}

Data Sources: Processed From The Questionnaire, September 2021

Based on Table XIII, it is known that the correlation coefficient (r) of the motivation variable on job satisfaction is 0.467 which indicates that the relationship between variables is quite strong.

Then, the value of the coefficient of determination (R2) is 0.218 , this means that $21.8 \%$ of the job satisfaction variable can be explained by the motivation variable and $78.2 \%$ is the influence of other variables. The relationship between Motivation on Commitment:

Table XIV: The Analysis of Correlation Coefficient (r) and Coefficient of Determination (R2) Motivation on Commitment

\begin{tabular}{|l|c|c|c|c|}
\hline \multicolumn{5}{|c|}{ Model Summary } \\
\hline Model & $R$ & $R$ Square & $\begin{array}{c}\text { Adjusted } R \\
\text { Square }\end{array}$ & $\begin{array}{c}\text { Std. Error of } \\
\text { the Estimate }\end{array}$ \\
\hline 1 & $0.676^{\mathrm{a}}$ & 0.457 & 0.454 & 2.423 \\
\hline
\end{tabular}

Data Sources: Processed From The Questionnaire, September 2021 Based on Table XIV, it is known that the correlation coefficient (r) of the motivation variable to commitment is 0.676 which indicates that the relationship between variables is strong. Then, the value of the coefficient of determination (R2) is 0.457 , this means that $45.7 \%$ of the commitment variable can be explained by the motivation variable and $54.3 \%$ is the influence of other variables. The Relationship between Commitment on Job Satisfaction:

Table XV: The Analysis of Correlation Coefficient (r) and Coefficient of Determination (R2) Commitment on Job Satisfaction

\begin{tabular}{|l|c|c|c|r|}
\hline \multicolumn{5}{|c|}{ Model Summary } \\
\hline Model & $R$ & $R$ Square & $\begin{array}{c}\text { Adjusted } R \\
\text { Square }\end{array}$ & $\begin{array}{c}\text { Std. Error of } \\
\text { the Estimate }\end{array}$ \\
\hline 1 & $0.482^{\mathrm{a}}$ & 0.233 & 0.218 & 5.450 \\
\hline
\end{tabular}

Data Sources: Processed From The Questionnaire, September 2021

Based on Table XV, it is known that the correlation coefficient ( $r$ ) of the commitment variable to job satisfaction is 0.482 which indicates that the relationship between variables is quite strong. Then, the value of the coefficient of determination (R2) is 0.233 , this means that $23.3 \%$ of the job satisfaction variable can be explained by the commitment variable and $76.7 \%$ is the influence of other variables.

The Relationship of Motivation on Job Satisfaction with Commitment as Mediation

Table XVI: The Analysis of Correlation Coefficient (r) and Coefficient of Determination (R2) Motivation on Job Satisfaction With Commitment as Mediation

\begin{tabular}{|l|c|r|r|r|}
\hline \multicolumn{5}{|c|}{ Model Summary } \\
\hline Model & $R$ & $R$ Square & $\begin{array}{c}\text { Adjusted } R \\
\text { Square }\end{array}$ & $\begin{array}{c}\text { Std. Error of } \\
\text { the Estimate }\end{array}$ \\
\hline 1 & $0.491^{\mathrm{a}}$ & 0.237 & 0.227 & 5.454 \\
\hline
\end{tabular}

Data Sources: Processed From The Questionnaire, September 2021 Based on Table XVI, it is known that the correlation coefficient (r) of the motivation variable on job satisfaction with commitment as a mediator is 0.491 which indicates that the relationship between variables is quite strong. Then, the coefficient of determination (R2) is 0.237 , this means that $23.7 \%$ of job satisfaction variables can be explained by motivation and commitment variables, while $76.3 \%$ is the influence of other variables.

\section{E. DISCUSSION}

\section{The Effect of Motivation on Job Satisfaction}

Based on statistical calculations that have been carried out, it is known that hypothesis 1 is accepted which means that motivation has a positive and significant effect on job satisfaction of online drivers in Ogan Ilir Regency. This shows that high work motivation can increase job satisfaction of online driver-partners in Ogan Ilir Regency. Jekiel (2011) in his book explains that motivation and satisfaction have a positive relationship where more satisfied individuals can lead to better job performance through their inner motivation. This relationship is in line with attribution theory that a person is motivated to do something because something that can come from within or outside the individual is able to motivate the individual to act to fulfill his desires. Research by Armstrong (2014) explains the relationship between motivation and satisfaction that job satisfaction canbe defined as the attitudes and feelings that people have about their work. A positive and pleasant attitude towards work indicates job satisfaction. Negative and unpleasant attitudes towards work indicate job dissatisfaction. One of the things that can distinguish them is through the motivation of each individual towards their work. Online drivers, as one of the business lines, is currently growing so rapidly that it houses many driver-partners. To increase the work motivation of driver-partners, there are several alternative ways that can be done, such as providing incentives if their work target exceeds the target set by the company at one time, giving coupons/vouchers for daily necessities even though the nominal is not large or increasing the income margin for partners. high-performing driver during one job. Good work motivation will encourage driver-partners to work optimally which in turn can increase job satisfaction.

\section{The Effect of Motivation on Commitment}

Based on statistical calculations that have been carried out, it is known that hypothesis 2 is accepted, which means that motivation has a positive and significant effect on the commitment of online drivers in Ogan Ilir Regency. This shows that high work motivation will increase the commitment of online driver-partners in Ogan Ilir Regency. In line with the theory put forward by Weiner (1980) the behavioral characteristics of someone who has motivation and commitment to work such as always getting closer to the tasks at hand rather than avoiding them, staying afloat when work becomes difficult and believing that the results obtained are determined by how hard a person tries.

Blue Eyes Intelligence Engineering \& Sciences Publication

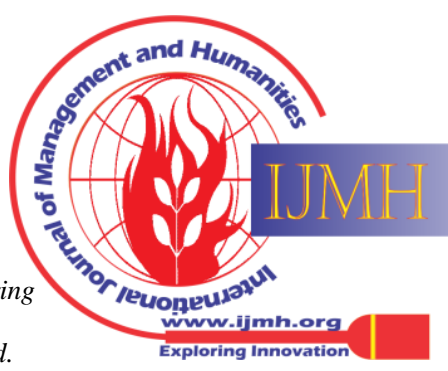


This is also supported by the results of research by Ahluwalia and Preet (2017) that the higher the work experience, the higher the individual's motivation to work so that the level of commitment also increases compared to individuals who have just worked.

One of the efforts made by online driver-partner companies in Ogan Ilir Regency is to provide enthusiasm and motivation to driver-partners, either in the form of gathering events in order to further familiarize themselves and appreciate their work or simply open a joint discussion to share things that are important to them. become a problem for the driver-partners while working as a material for company evaluation. Driver-partners who increase their work motivation will do a good job and will have a higher commitment to the company.

\section{The Effect of Commitment on Job Satisfaction}

Based on statistical calculations that have been carried out, it is known that hypothesis 3 is accepted, which means that commitment has a positive and significant effect on job satisfaction of online drivers in Ogan Ilir Regency. This shows that a high commitment will increase the job satisfaction of online driver-partners in Ogan Ilir Regency. Research conducted by Loan (2020) explains that increasing job satisfaction will increase organizational commitment to improve individual work performance. In line with the attribution theory developed by Weiner (1971) that there is a causality locus dimension that determines the satisfaction experienced by individuals related to achieving their goals through the efforts that individuals make and a stability dimension that determines one's commitment to consistency in maintaining their tasks. In this regard, online driver-partners who have the desire to be associated with the company will maximize their all ability while carrying out their duties and responsibilities. An online driver-partner who goes out of his way with a commitment to work consistency will help increase job satisfaction. The higher the commitment of the driver-partners, the higher the job satisfaction they will have. Things that companies can do by being responsible for their obligations and giving driver-partners rights consistently and fairly, giving affection in the form of attention to events that happen to their driver-partners and being proactive to provide feedback on every evaluation material from their driver-partners.

\section{The Effect of Motivation on Job Satisfaction Mediated by Commitment}

Based on the results of statistical analysis in tables 26 and 27 in the statistical calculation table that has been carried out, it shows that hypothesis 4 which means commitment successfully mediates between work motivation and job satisfaction of online driver-partners in Ogan Ilir Regency. Although commitment has succeeded in being a mediating variable, commitment does not fully mediate (full mediation) between motivation and job satisfaction. This happens because basically the motivation and job satisfaction of employees already have a significant relationship so that commitment is only a partial mediation variable.

According to Suliyanto (2011) partial mediation directly or indirectly on the independent variable affects the dependent variable. Partial mediation states that the mediating variable contributes some or all of the relationship between the independent variable and the dependent variable. Partial mediation implies that there is not only a significant relationship between the mediator and the dependent variable, but also some direct relationship between the independent and dependent variables. The results of the analysis in this study are supported by previous researchers Hussain et al. (2013) that there is a positive and significant relationship between motivation and satisfaction through commitment that mediates the relationship between the two.

Therefore, motivation variables, commitment variables and job satisfaction variables are important factors for companies to provide proper treatment to driver-partners so that they can achieve company goals and provide welfare for online driver-partners in Ogan Ilir Regency.

\section{The Theoretical Implication Of Research}

The implication From the results of research on the effect of motivation on job satisfaction with commitment as a mediating variable on online driver partners in Ogan Ilir Regency, there is a mutually influencing relationship between variables. These variables determine the motives and causes of a person's behavior as described in attribution theory. Luthans (2005) explains that in carrying out activities, individuals will form perceptions in the form of ideas or ideas about other people and the surrounding conditions that cause individual behavior and actions. In connection with that, this study shows that there is an influence of motivation on job satisfaction which is partially mediated by commitment, meaning that motivated driver partners will also increase their job satisfaction, although commitment mediates partially, not fully, this happens because basically motivation and Job satisfaction already has a significant relationship, so commitment is only a mediating variable in part of the relationship between the two. This relevance is supported by Borkowski (2011) that the process of attribution of a person's behavior starts from the personality that emerges from the workplace, where the driver-partners think whether an event comes from themselves or not related to the motives (push) of the driver-partner at their place of work that raises motivation to be enthusiastic at work or not in the form of a response, one of which is job satisfaction. In the results of this study, driver partners who are passionate about work will get a better level of job satisfaction. Thus, the incident will form an action in the form of a sense of responsibility or not for the driver-partners which is realized in the form of a commitment. Although the commitment to mediate partially because the relationship between motivation and satisfaction is significant, commitment can still have an indirect influence on the motivation and job satisfaction of online driver partners in Ogan Ilir Regency.

\section{The Practice Implication Of Research}

Online transportation, as one of the business lines, are currently growing so rapidly that it houses many driver partners. To increase the work motivation of driver partners, there are several alternative ways that can be done, such as providing incentives if their work target exceeds the target set by the company at one time, giving coupons/vouchers for daily needs even though the nominal is not large or increasing the income margin for the driver. a high-performing driver partner during one working

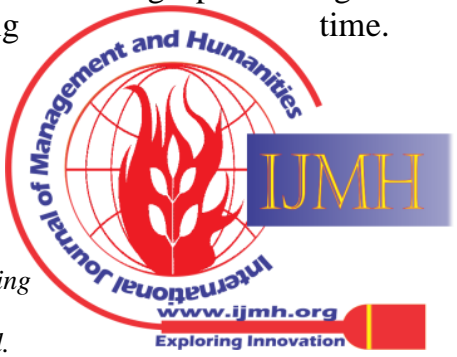




\section{The Effect of Motivation on Job Satisfaction with Commitment as Mediation Variable (Case Study on Online Driver Partner of Technology Companies in Ogan Ilir Regency)}

Good work motivation will encourage driver partners to work optimally which in turn can increase job satisfaction. Thus, online driver-partners who previously had low work motivation can provide higher morale such as increasing pick-up time for orders, providing better service for consumers and companies as well as being more enthusiastic which is manifested by enthusiasm in working to achieve the desired target and contribute more to the company's growth.

Then, to increase the commitment of online driver-partners, it can be held through events in the form of gathering events as a series of events to familiarize themselves and appreciate their work or simply open a joint discussion to share things that become problems for driver-partners while working as material for company evaluation.

Thus, online driver-partners who previously thought the company was normal have become more loyal to the company. That way, a form of increased work commitment for online driver-partners who were previously less consistent and often offline in their work to become more consistent in doing on bids, driver-partners who do not want to pick up orders in situations that are not desirable based on personal interests, change to have a commitment better awareness to serve consumers regardless of the circumstances, is reflected in the loyalty of driver partners who are willing to make greater sacrifices, both physically and mentally at work.

Meanwhile, to increase job satisfaction, companies can do several things, namely by being responsible for their obligations and providing driver-partners' rights consistently and fairly, giving affection in the form of attention to events that happen to their driver-partners and being proactive to provide feedback on each evaluation material. from the driver's partner. That way, online driver-partners who previously often complained at work can be appreciative of their work, be more objective about their performance results and be more introspective in their work as an effort to improve joint performance. Therefore, the motivation variable, the commitment variable and the job satisfaction variable are important factors by providing proper treatment to driver-partners so that they can achieve company goals and provide welfare for online driver-partners in Ogan Ilir Regency.

\section{V.CONCLUSION}

Based on the results of the research conducted, the following conclusions can be drawn:

1. Motivation has a positive and significant effect on the job satisfaction of online drivers-partener in Ogan Ilir Regency.

2. Motivation has a positive and significant effect on the commitment of online drivers-partener in Ogan Ilir Regency.

3. Commitment has a positive and significant effect on the job satisfaction of online drivers-partener in Ogan Ilir Regency.

4. Motivation has a positive and significant effect on the job satisfaction with commitment as a mediating variable on online drivers-partener in Ogan Ilir Regency.

\section{SUGGESTIONS}

The suggestions that can be given to further researchers are:

1. Further researchers can conduct research in other regencies/cities that have technology companies in the field of online transportation service providers or other types of services on a larger scale at the provincial or regional level to increase the knowledge base.

2. Further researchers are advised to add or use other variables such as work involvement, work stress, compensation, leadership and performance in order to enrich the substance of the research that has been done.

\section{LIMITATIONS}

Some limitations in this research are:

1. The research variables used are still few, this is reflected in the percentage of the influence of other variables outside the research variables is still quite large so that further research is needed on other variables such as work involvement, work stress, compensation, leadership and performance to add references further research.

2. A relatively small sample, namely online transportation service technology companies in Ogan Ilir Regency where there are still many other technology companies engaged in services with larger company sizes and wider research scales, for example at the provincial or regional level in Sumatra.

\section{REFERENCES}

1. Adekola, B. 2012. The Impact of Organizational Commitment on Job Satisfaction: A Study of Employees at Nigerian Universities. International Journal of Human Resource Studies, 2(2), 1.

2. Ahluwalia dan Preet. 2017. Work Motivation, Organizational Commitment and Locus of Control vis-a-vis Work Experience amongst University Teachers. SIBM Pune Research Journal, Vol XIV, 26-33, December 2017.

3. Akhar et al. 2015. The Impact of Organizational Commitment on Job Satisfaction and Job Performance: An Empirical Study from Pakistan. IOSR Journal of Business and Management. e-ISSN: 2278-487X, p-ISSN: 2319-7668. Volume 17, Issue 6.Ver. II, PP 75-80.

4. Alesi et al. 2019. International Journal of Environmental research and public health. Res. Public Health 2019, 16, 2702.

5. Al-Sada, M., B. Al-Esmael, dan M.N. Faisal. 2017. Influence of organizational culture and leadership style on employee satisfaction, commitment and motivation in the educational sector in Qatar. EuroMed Journal of Business, 12(2),163-188.

6. Appelbaum, E., T. Bailey, P. Berg dan A.L. Kalleberg. 2000. Manufacturing Advantage: Why high performance work systems pay off, Ithaca, NY,ILR Press.

7. Arikunto dan Suharsimi. 2002. Metodologi PenelitianSuatu Pendekatan Proposal. Jakarta. PT Rineka Cipta.

8. Armstrong. 2012. Armstrong's Handbook of Human Resource Management Practice. UK. Koganpage.

9. Armstrong. 2014. Armstrong's Handbook of Human Resource Management Practice. UK. Koganpage.

10. Badan Pusat Statistik. 2015. Jarak dari Ibukota Kabupaten Ogan Ilir ke Setiap Ibukota Kecamatan yang ada di Kabupaten Ogan Ilir .https://oganilirkab.bps.go.id/statictabel/2015/10/01/10/jarak-dari-ibuk ota-kabupaten-ke-ibukota-kecam atan-di-kabupaten-ogan-ilir.html. Diakses pada tanggal 20 Februari 2021.

11. Badan Pusat Statistik. 2020. Jumlah Kendaraan Bermotor di Indonesia. Badan Pusat Statistik Republik Indonesia.

12. Baron, R.M. dan D.A. Kenny. 1986. The Moderator-Mediator Variable Distinction in Social Psychological Research: Conceptual, Strategic, and Statistical Considerations. Journal of personality and Social Psychology. 51 (6), 1173-1182.

13. Berg, Van Den. 2011. Exploring Possible Relationships Between Motivation and Commitment. MasterThesis Psychology. University of Twente.

14. Borkowski. 2011. Ogranizational Behavior in Health Care. USA. Jones and Bartlett Publishers.

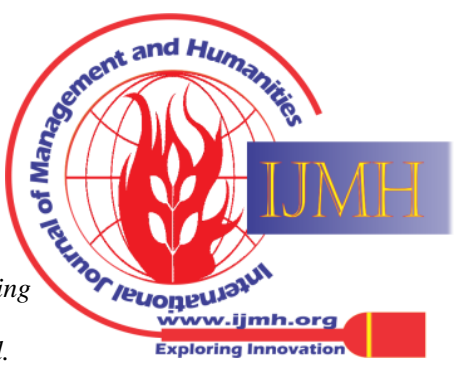


15. Decenzo dan Robbins. 2010. Fundamentals of Human Resource Management. USA. John Willey and Sons, Inc.

16. Dessler. 2013. Human Resource Management. USA.Pearson.

17. Faddul dan Danaiata. 2019. The Influence Of Leadership Style On Teachers' Job Motivation and Satisfaction In The Druze Sector Of Israel. Romania. Timisoara Journalof Economics and Business.

18. Fanggidae, Rolland Epafras. 2017. The Influence of Spirituality Workplace to Motivation, Job Satisfaction and Organizational Commitment.Indonesia. Global Journal of Business and Social Science Review.

19. Ghozali, Imam. 2018. Aplikasi Analisis Multivariate dengan Program SPSS. Semarang. Badan Penerbit Universitas Diponergoro.

20. Heider, F. 1958. The psychology of interpersonal relations. New York: John Wiley \& Sons.

21. Jekiel. 2011. Lean Human Resource Redesigning HR Processes for a Culture of Continuous Improvement. New York. Taylor and Francis Group.

22. Mitonga, M.J. 2018. Ethical climate influences on employee commitment through job satisfaction in a transport sector industry, Journal of Psychology in Africa, 28:1, 15-20.

23. Kelly, J. 2015, The Relationship Between Organisational Commitment And Job Satisfaction Of Commissioned Officers Within An Arm Of The South African National Defence Force, Thesis, Faculty of Economic and Management Science, University of the Western Cape.

24. Kochan, T.A. dan L. Dyer. 1993. Managing transformational change: the role of human resource professionals. International Journal of Human Resource Management, 4 (3), pp 569-90.

25. Kominfo. 2015. Indonesia Raksasa Teknologi Digital Asia.https://kominfo.go.id/content/detail/6095/indonesia-raksasa-tek nologi digital-asia/0/sorotan_media.Diakses pada 20 Februari 2021.

26. KumparanTech. 2020. Organisasi Ojol: Ada 4 JutaDriverOjol di Indonesia. $\quad$ https://kumparan.com/kumparantech/organisasi-ojo l-ada-4-juta-pengemudi-ojol-di-indonesia-1tBrZLE $\underline{\text { XOEI. }}$ Diakses pada 20 Februari 2021.

27. Lee et al. 2014. The Influence of VolunteerMotivation On Satisfaction, Attitudes, and Support For A Mega Event. International Journal Of Hospitality Management 40 (2014) 37-48.

28. Loan. 2020. The influence of organizational commitment on employees' job performance: The mediating role of job satisfaction. Management Science Letters,10(2020) 3307-3312.

29. Locke, E. A. 1976. The nature and causes of job satisfaction, in (ed) M D Dunnette, Handbook of Industrial and Organizational Psychology, Chicago,Rand McNally, pp 1297-343.

30. Luthans, F. 2005. Perilaku Organisasi (Transleted). Yogyakarta. Andi.

31. Madi et al. 2017. The Impact of Employee Motivation on Organizational Commitment. Yordania. European Journal of Business and Management, Vol.9, No.15, 2017.

32. Malik et al. 2017. Influence of transformational leadership components on job satisfaction and organizational commitment. Pakistan. Pakistan Journal of Commerce and Social Sciences (PJCSS), Lahore, Vol. 11, Iss. 1 , pp. $147-166$

33. Mangkunegara dan Octorend. 2015. Effect of Work Discipline, Work Motivation and Job Satisfaction on Employee Organizational Commitment in the Company (Case Study in PT. Dada Indonesia). Universal Journal of Management 3(8): 318-328.

34. Marzuki. 2000. Metodologi Riset. Yogyakarta. Badan Penerbit Fakultas Ekonomi Universitas Islam Indonesia. Mowday dan Steers. 1979. The Measurement of Organizational Commitment. Journal of VocationalBehavior 14, 224-247.

35. Mowday, R., L. Porter dan R. Steers. 1982. Employee organization Linkages: The psychology of commitment, absenteeism and turnover, London,Academic Press.

36. Mowday, R., L. Porter dan R. Steers. 1982. Employee organization Linkages: The psychology of commitment, absenteeism and turnover, London,Academic Press

37. Ngoc, Mai Nguyen. 2017. mpirical Study of the Relationships between Loyalty, Motivation, Satisfaction and Commitment of Talents at Commercial Banks in Vietnam. Vietnam. International Journal Of Business, Social And Scientific Research Volume: 6, Issue: 1, Page: 13-17.

38. Nor et al. 2020. Human Resources Management Practices and its Impact on Employee Commitment Mong Staffs of Road Transport Department, Perak, Malaysia. Journal of Environmental Treatment Techniques, Volume 8, Issue 1, Pages: 28-34.

39. Ocen, E., Francis, K., \& Angundaru, G. 2017. The role of training in building employee commitment: the mediating effect of job satisfaction. European Journal of Training and Development, 41(9), 742-757.

40. Ose et al. 2019. Relationship Between Motivation and Job Satisfaction of Staff in Private University Libraries, Nigeria. Academy of Strategic

Published By:

Blue Eyes Intelligence Engineering

\& Sciences Publication

Management Journal. Volume 18, Issue 1, 2019.

41. Paais dan Pattiruhu. 2020. Effect of Motivation, Leadership, and Organizational Culture on Satisfaction and Employee Performance. 列 8 (2020) 577-588

42. Putra , S.T., dan A. Prasetya. 2018. The Influence of Reward, Work Place Environment, And Career Growth to Job Satisfaction And Their Impaction On Organizational Commitment. Jurnal Administrasi Bisnis (JAB).Vol. 64 No. 1 November 2018.

43. Stankovska et al. 2017. Job Motivation and Job Satisfaction Among Academic Staff in Higher Education. BCES Conference Books, 2017, Volume 15. Sofia: Bulgarian Comparative Education Society.

44. Sugiyono. 2016. Metode Penelitian Kuantitatif, Kualitatif dan R\&D, Bandung, Alfabeta.

45. Suliyanto. 2011. Ekonometrika Terapan Teori dan Aplikasi dengan SPSS. Yogyakarta. CV Andi.

46. Taba, Idrus Muhammad. 2018. Mediating Effect of Work Performance and Organizational Commitment in Relationship between Reward stem and Employees' Work Satisfaction in South Sulawesi. Indonesia. Journal of Management Development, Emerald Insight, https://doi.org/10.1108/JMD-11-2016-0256.

47. Tella et al. 2007. Work Motivation, Job Satisfaction, and Organisational Commitment of Library Personnel in Academic and Research Libraries Oyo State, Nigeria. Library Philosophy and Practice 2007.

48. Thamrin. 2012. The Influence of Transformational Leadership and Organizational Commitment on Job Satisfaction and Employee Performance. nternational Journal of Innovation, Management and Technology, Vol. 3, No. 5.

49. Veithzal et al. Oktober 2015. Manajemen Sumber Daya Manusia Untuk Perusahaan. Jakarta. RajaGrafindo Persada Veithzal et al. Oktober 2015. Manajemen Sumber Daya Manusia Untuk Perusahaan. Jakarta. RajaGrafindo Persada.

50. Zhang et al. 2019. A successful delivery process of green buildings: The project owners' view, motivation and commitment. Renewable Energy 138 (2019) 651e658.

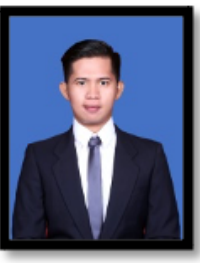

\section{AUTHORS PROFILE}

Denny Nabawi, S.E. Student In Master Of Management , Economic Faculty of Sriwijaya University, Palembang, South Sumatra, Indonesia

Prof. Badia Perizade, M.B.A., Ph.D. Lecturer In Master of Management, Economic Faculty of Sriwijaya University, Palembang, South Sumatra, Indonesia

Isni Andriana, S.E., M.Fin., Ph.D. Lecturer In Master of Management, Economic Faculty of Sriwijaya University, Palembang, South Sumatra, Indonesia 